\title{
O PROGRAMA DE POLÍTICA CRIMINAL BRASILEIRO: FUNÇÕES DECLARADAS E REAIS \\ contribuições de Claus Offe para fundamentação da crítica criminológica à teoria jurídica das penas
}

\section{Maurício Stegemann Dieter}

\section{RESUMO}

Claus OFFE define a dominação política em sociedades capitalistas como dominação de classe. Sua construção teórica afirma que as ações políticas de formulação e implementação dos fins capitalistas gerais são realizadas pelas atividades estatais de regulação e repressão. Ambas são marcadas pela seletividade, definida como exclusão não-eventual de possibilidades alternativas (e eventualmente contrárias) aos interesses capitalistas. Como atividades seletivas orientadas aos fins do mercado, as ações estatais devem ter seus objetivos reais ocultos; a tarefa de escamotear os reais fins da atividade estatal cabe ao discurso oficial, traduzido pela legalidade e legitimado pelo argumento democrático. O programa de política criminal é uma ação estatal, sujeita como tal às contribuições teóricas do sociólogo alemão. O Direito Penal - como formulação legal do programa de política penal do Estado - justifica-se na teoria jurídica das penas, que atribui à sanção criminal a função de reprovar e prevenir o crime. Entretanto, diante da falência estrutural do sistema de execuções penais no Brasil, compreende-se o discurso oficial da pena criminal como mera retórica, criada com o propósito de ocultar suas funções reais, identificadas pela Criminologia Radical. A pena, aplicada e executada de acordo com a utilidade do condenado, evidencia o Direito Penal como instrumento de garantia das relações de produção capitalista, por meio da gestão diferencial da pobreza.

Palavras-chave: Criminologia Radical, Função da Pena, Teoria Crítica das Penas.

* Especialista em Direito Penal e Criminologia pelo Instituto de Criminologia e Política Criminal (2006). Mestrando em Direito do Estado pela Universidade Federal do Paraná. Pesquisador do Max-Planck-Institut für ausländisches und internationales Strafrecht. Email: mauriciodieter@yahoo.com.br 
SUMÁRIO: 1 INTRODUÇÃo; 2 BREVE SÍNTESE DAS CONTRIBUiÇões de Claus OFFE NA DEFINIÇÃO DE DOMINAÇÃO POLÍTICA COMO DOMINAÇÃO DE CLASSE EM ESTADOS CAPITALISTAS; 3 O ATUAL ESTADO DO DEBATE TEÓRICO CRÍTICO SOBRE O PROGRAMA DE POLÍTICA PENAL BRASILEIRO; 3.1 AS FUNÇÕES ATRIBUídAs À PENA NO DISCURSO OFICIAL; 3.2 AS VERDADEIRAS FUNÇÕES DA PENA: UMA REFLEXÃO A PARTIR DA CRIMINOLOGIA RAdiCAL; 4 CONSIDERAÇÕES FINAIS: A CONVERGÊNCIA DE SENTIDO ENTRE AS CONCLUSÕES DA CRIMINOLOGIA CRÍTICA E A PROPOSTA TEÓRICA DE Claus OFFe; 5 REFERÊNCIAS.

\section{INTRODUÇÃO}

O ensaio tem por objeto uma releitura da crítica criminológica ao programa de política criminal brasileiro a partir de algumas categorias propostas por Claus Offe.

Tendo em vista a compreensão do domínio político como domínio de classe na sociedade capitalista, o referente teórico é identificar a convergência de sentido entre as conclusões do autor e da criminologia crítica sobre as funções reais e declaradas da pena criminal nos Estados capitalistas, enfrentando o papel problemático da legitimação da ação estatal e do uso da repressão criminal para realização dos fins de mercado.

A metodologia consiste de sucinta revisão bibliográfica de excertos da obra "Problemas Estruturais do Estado Capitalista" de Claus Offe, apresentação sintética do atual debate criminológico sobre o programa de política penal no Brasil e, finalmente, análise que complemente com os conceitos do autor alemão à teoria crítica sobre os fins da pena.

Justifica-se o texto na necessidade permanente de atualização teórica da Criminologia Crítica, especialmente pela contribuição sociológica contemporânea. 
O PROGRAMA DE POLÍTICA CRIMINAL BRASILEIRO: FUNÇÕES DECLARADAS E REAIS (CONTRIBUIÇÕES DE ClAUS OFFE PARA FUNDAMENTAÇÃo DA CRÍTICA CRIMINOLÓGICA À TEORIA JURÍDICA DAS PENAS)

Além disso, sem uma teoria crítica do Estado é difícil compreender o percurso do labelling approach, como categoria fundamental para uma criminologia crítica, do interacionismo simbólico para as relações estruturais.

O método consiste na dedução lógica a partir de premissas teóricas críticas.

Como procedimento metodológico, segue-se o seguinte roteiro: primeiro, apresenta-se a teoria que caracteriza dominação política como dominação de classe em Claus Offe; segundo, apresenta-se em linhas gerais o atual estado do debate científico sobre o programa de política penal brasileiro; terceiro, apresenta-se sucinta revisão sobre a teoria jurídica da pena; quarto, explana-se sobre a crítica radical às funções da pena em Estados capitalistas; por último, aponta-se para uma adequação de sentido entre a teoria das penas na criminologia radical e a crítica de Claus Offe.

\section{BREVE SÍNTESE DAS CONTRIBUIÇÕES DE CLAUS OFFE NA DEFINIÇÃO DE DOMINAÇÃO POLÍTICA COMO DOMINAÇÃO DE CLASSE EM ESTADOS CAPITALISTAS}

Claus Offe busca compreender a relação objetiva e complementar entre domínio político e econômico na sociedade capitalista e os mecanismos que asseguram essa relação, com o propósito de resolver a inconsistência teórica relativa ao caráter classista do Estado. Sua construção teórica visa superar o alcance das duas grandes teorias - e suas derivações conhecidas - usualmente utilizadas para tentar explicar o papel do Estado capitalista.

A primeira é conhecida como a teoria da influência, que concebe o Estado como mero instrumento dos interesses capitalistas, cuja influência determinaria a orientação da atividade estatal. Essa influência capitalista sobre o Estado pode acontecer de diversas formas, como lobby político, infiltração de agentes capitalistas no espaço burocrático, ameaça de transferência de renda ou queda de produção, uso dos meios privados de comunicação de massa para dirigir a opinião pública ou 
financiando a democracia representativa ${ }^{1}$. As estratégias não se excluem, sendo complementares no objetivo de persuadir o Estado para realizar os fins do mercado. Sem negar o tremendo poder de influência do mercado no momento de definir políticas estatais $^{2}$, Offe considera a teoria da influência insuficiente para explicar o caráter classista do Estado, dada a falta de garantia estrutural para a eficácia da influência. O Estado pode estar imune à influência capitalista ou essa influência pode ser irrelevante e até ensejando decisões contrárias, o que de certa forma já evidenciaria que não é mero instrumento de uma classe. O risco da decisão desfavorável, resistente à influência capitalista, é excessivamente oneroso para um mercado que requer previsibilidade.

A segunda é definida como teoria dos fatores limitativos ${ }^{3}$. Em seus termos, as instituições do sistema político estariam estruturalmente subordinadas às condições impostas pelas estruturas capitalistas, não tendo autonomia para agir segundo outra racionalidade. Ao mercado caberia, portanto, fixar os limites para atividade estatal. Novamente, Offe afirma que a teoria é insuficiente, porque depende da definição de interesses capitalistas globais, uma lógica incompatível com a concorrência de mercado $^{4}$, até porque o capitalismo não convive em bases solidárias ${ }^{5}$.

Além de seus problemas específicos, ambas as teorias erram na medida em que pressupõem a neutralidade do aparelho estatal, que é apenas influenciado ou objetivamente limitado. Admitindo que o Estado seja neutro, tornam-se incapazes de demonstrar seu caráter classista, bem como a necessidade estrutural desse caráter ${ }^{6}$.

A proposta teórica de Offe parte do fato de que o mercado reiteradamente

${ }^{1}$ OFFE, Claus. Problemas estruturais do Estado capitalista. Rio de Janeiro: Tempo Brasileiro, 1984, p. 122-123. Apenas para comparação, em oposição e adepto à teoria da influência CHOMSKY, Noam. Para entender o poder: o melhor de Noam Chomsky. Trad. Eduardo Francisco Alves. Rio de Janeiro: Bertrand Brasil, 2005.

${ }^{2}$ OFFE, op. cit., p.126-127.

${ }^{3}$ Ibidem, p.142-143.

${ }^{4}$ Ibidem, p. 142-144.

${ }^{5}$ Ibidem, p. 122, 144-145.

${ }^{6}$ Ibidem, p. 144. 
O PROGRAMA DE POLÍTICA CRIMINAL BRASILEIRO: FUNÇÕES DECLARADAS E REAIS (CONTRIBUIÇÕES DE ClAUS OFFE PARA FUNDAMENTAÇÃo DA CRÍTICA CRIMINOLÓGICA À TEORIA JURÍDICA DAS PENAS)

vale-se do Estado para alcançar legitimação, uma condição necessária para sua expansão. Postula-se que o capitalismo não tem por objetivo afirmar-se como superior à regra estatal, sendo capaz de violá-la a qualquer tempo; antes, quer ser legitimado pela legalidade, estabelecendo sua racionalidade como condição de existência e validade das normas estatais ${ }^{7}$. O objetivo final da racionalidade de mercado é transformar o "Estado inserido em uma sociedade capitalista" em um próprio "Estado capitalista",

Considerando estas premissas fundamentais, Offe define a dominação organizada pelo Estado como um "sistema de regulamentação seletivo"9. A seletividade significa a "restrição não aleatória (isto é, sistêmica) de um espaço de possibilidades" ${ }^{\prime 10}$, ou seja, a atividade estatal deve ser capaz de selecionar determinadas ações políticas em detrimento de outras igualmente possíveis, sendo a escolha determinada pelos interesses da classe capitalista. Em outras palavras, as ações estatais - como ações políticas -, devem ter seu fím definido pela necessidade de mercado ${ }^{11}$, e que devem existir no interior do aparelho estatal elementos que garantam essa orientação classista ${ }^{12}$.

Consoante esta ordem de idéias, o primeiro problema que se apresenta para a dominação estatal é a identificação dos "fins gerais do mercado". Trata-se de atribuição das mais complexas porque, como visto, os objetivos da classe capitalista são heterogêneos e, geralmente, conflitantes. Nada obstante, exige-se do Estado que desenvolva uma seletividade que sirva à unificação e destilação dos interesses capitalistas "globais", mesmo que contra determinado grupo de interesse. Tal sistema funciona segundo regras de exclusão ${ }^{13}$, responsáveis pela adequação dos fins das

${ }^{7}$ E não apenas fixando-lhe os limites de atuação, como na teoria dos fatores limitativos, acima. Para clarificar, OFFE, op. cit., p. 145-146.

${ }^{8}$ Ibidem, p. 146-151.

${ }^{9}$ Ibidem, p. 151.

${ }^{10}$ Ibidem, loc. cit.

${ }^{11}$ Ibidem, p. 150.

12 Ibidem, p. 150-151.

${ }^{13}$ Essas regras de exclusão, no entanto, não compreendem: a) os acontecimentos que não 
ações estatais aos fins do mercado ${ }^{14}$. Para Offe, o Estado capitalista logra essa difícil definição de "fins gerais" por meio de ações seletivas com o propósito de regulação.

Além disso, a atividade seletiva estatal deve proteger o mercado dos conflitos que nascem pela efetiva implementação dos interesses capitalistas "globais". E o Estado capitalista faz isso por meio de novas ações políticas seletivas, desta vez com o propósito de repressão ${ }^{15}$.

Logo, a seletividade estatal é identificada nas ações políticas de regulação dos fins capitalistas e repressão dos interesses divergentes. A primeira revela o aspecto positivo da intervenção estatal, que disciplina o desenvolvimento da atividade capitalista de acordo com os interesses capitalistas "globais", protegendo o mercado de sua autofagia. A segunda evidencia o aspecto negativo da intervenção, como sanção ou ameaça de sanção para quem se opõe à implementação dos interesses gerais do mercado. Em síntese, regulação e repressão, como atividades seletivas estatais, garantem o caráter classista do Estado ${ }^{16}$.

Offe afirma que a identificação dos interesses capitalistas nas ações políticas de regulação e repressão é condição necessária, porém não suficiente para definir o Estado como "Estado capitalista". É necessário, ainda, a comprovação empírica de que ações políticas alternativas foram rejeitadas, definindo os acontecimentos excluídos pela intervenção estatal. Desta forma, a seletividade da ação política só pode ser analisada depois de sua implementação, sendo inconsistente, do ponto de vista teórico, tentar antecipar quais acontecimentos serão excluídos pela seletividade estatal ${ }^{17}$.

Esses "não-acontecimentos" podem ser identificados a partir do contexto da

ocorrem porque pertencem a diferentes momentos históricos (explicados pela exclusão sócioestrutural), b) os que não acontecem por acaso (explicados pela exclusão acidental) e c) tudo aquilo que acontece independentemente de processos estruturais (excluídos de modo sistêmico).

${ }^{14}$ OFFE, op. cit., p.151-154.

${ }^{15}$ Ibidem, p. 153-154.

${ }^{16}$ Ibidem, p. 154.

${ }^{17}$ Para OFFE, “o problema da teoria do Estado que quer comprovar o caráter classista da dominação política e sua cumplicidade estrutural com o interesse do capital global" é o fato de que como "teoria" é muito ruim, pois só é possível observar a seletividade em benefício do interesse capitalista global depois que ele é feito. Ibidem, p. 154-158. 
O PROGRAMA DE POLÍTICA CRIMINAL BRASILEIRO: FUNÇÕES DECLARADAS E REAIS (CONTRIBUIÇÕES DE ClAUS OFFE PARA FUNDAMENTAÇÃo DA CRÍTICA CRIMINOLÓGICA À TEORIA JURÍDICA DAS PENAS)

práxis política e avaliados pelo confronto de processos político-administrativos com as incongruências práticas que sistematicamente aparecem. Por um lado, a identificação dos não-acontecimentos é fácil, porque são evidentes e inegáveis os efeitos reais produzidos pelas ações políticas. Por outro, e paradoxalmente, a avaliação destas aspirações negadas não é simples. Pelo contrário, caracterizar a seletividade como manutenção do interesse de classes é tarefa extremamente complexa, porque a “dominação política em sociedades industriais capitalistas é o método da dominação de classes que não se revela como tal" ${ }^{18}$.

O ocultamento do sentido real de valorização das ações estatais é uma condição para manter a base do poder preservada e diferenciada do mercado, de modo a continuar legitimando suas ações como produto da vontade coletiva: a dominação política oculta seu caráter classista para poder justificar-se como poder ${ }^{19}$.

Se demonstrado que as ações políticas realizam apenas os objetivos da classe capitalista, provoca-se uma permanente crise de credibilidade do sistema. Por isso a independência do Estado em relação ao mercado é um mito que deve ser perpetuado; nas palavras do autor, a "funcionalização da soberania exige que o aparelho estatal assuma funções de classe sob pretexto da neutralidade de classe e invoque o álibi do universal para o exercício do poder particular"20.

Com essa estratégia, o Estado evita a polarização das classes mercado e sociedade, como esclarece Offe:

O problema estrutural do Estado capitalista é que ele precisa simultaneamente praticar e tornar invisível o seu caráter de classe. As operações de seleção e direcionamento de caráter coordenador e repressor, que constituem conteúdo de seu caráter classista, precisam ser desmentidas por uma terceira categoria de operações seletivas de caráter ocultador: as operações divergentes, isto é, as que seguem direções opostas. Somente a preservação da aparência da neutralidade da classe permite o exercício da dominação de classe ${ }^{21}$.

\footnotetext{
${ }^{18}$ Ibidem, p. 162.

${ }^{19}$ Ibidem, p. 162-164.

${ }^{20}$ Ibidem, p. 163.

${ }^{21}$ Ibidem, loc. cit.
} 
Em síntese, o objetivo da dominação política é a instauração e ocultamento de uma dominação de classe. Fundada a premissa fundamental que explica o caráter classista do Estado, Offe apresenta três níveis nos quais é possível identificar a simultaneidade entre instauração/ocultamento da dominação política de classe.

Primeiro, essa atividade de instauração-negação deve ser simultânea e convergente; uma ação estatal altera a estrutura e a economia em favor da classe capitalista ao mesmo tempo em que se anuncia como produto de decisões democráticas $^{22}$. De fato, a democracia burguesa - geralmente radicada na idéia de soberania popular - alivia com sucesso as contradições do capitalismo, a tal ponto que suas estruturas formais são consideradas indispensáveis à manutenção das relações de $\operatorname{produção~}^{23}$.

Segundo, a ação política deve apresentar uma disjunção entre objetivos declarados e reais; a dissonância entre discurso oficial e motivação real é estrutural ao sistema capitalista ${ }^{24}$. Em termos mais simples, uma ação política deve realizar o objetivo da classe capitalista, mas ter uma justificativa racional fundada em uma lógica fora do conflito de classes. Essa necessidade de convencimento da base social explica o uso intenso da propaganda nos Estados capitalistas ocidentais.

Terceiro, é preciso saber até que ponto o discurso oficial segura o antagonismo entre objetivos declarados e efeitos reais dos atos estatais. Isso porque a discrepância entre objetivos reais e declarados gera interferência e crise política, ruídos incômodos que podem colocar em xeque a legitimidade do Estado para implementar a dominação de classe sem correr riscos ${ }^{25}$. Quando os problemas provocados pela estrutura capitalista são identificados como problemas de política estatal, surge uma grave crise de legitimidade, que torna evidente o caráter de dominação de classe oculto do

\footnotetext{
${ }^{22}$ Ibidem, p. 166-167.

23 Seguindo o pensamento de outros autores, OFFE constata que democracia burguesa corresponde à relação de produção capitalista, exceto apenas no período fascista. Ibidem, p. 163.

${ }^{24}$ Ibidem, p. 167.

${ }^{25}$ Ibidem, p. 167-168.
} 
O PROGRAMA DE POLÍTICA CRIMINAL BRASILEIRO: FUNÇÕES DECLARADAS E REAIS

(CONTRIBUIÇÕES DE ClAUS OFFE PARA FUNDAMENTAÇÃo DA CRÍTICA CRIMINOLÓGICA À TEORIA JURÍDICA

DAS PENAS)

Estado $^{26}$

Sabendo que a crise é o resultado provável da implementação e ocultação da dominação de classe, o Estado adota medidas para lidar com ela, por meio de duas estratégias: reduzindo a probabilidade da emergência de conflitos ou o impacto de suas manifestações. O uso da repressão e da disciplina tem assim o objetivo de enfraquecer os conflitos políticos inevitáveis e canalizá-los para as trilhas institucionalizadas ${ }^{27}$.

O horizonte teórico projetado pela teorização acima esboçada constitui a síntese do pensamento de Claus Offe considerada pertinente para a análise da teoria jurídica e crítica da pena criminal, referente teórico a seguir apresentado.

\section{O ATUAL ESTADO DO DEBATE TEÓRICO-CRÍTICO SOBRE O PROGRAMA DE POLÍTICA PENAL BRASILEIRO}

A política criminal constitui o programa oficial do Estado para enfrentar os fenômenos descritos como "crime" e "criminalidade". No Brasil, a formulação legal desse programa oficial (por meio das leis penais) apresenta a pena como única resposta do Estado para o controle social do crime e da criminalidade, excluindo a possibilidade de políticas públicas alternativas ${ }^{28}$.

\section{${ }^{26}$ Ibidem, p.163.}

${ }^{27}$ Ibidem, p. 172.

${ }^{28}$ Não é sem propósito que o termo "política penal" é utilizado aqui como sinônimo de "política criminal". Para resolver a confusão conceitual entre "política criminal" e "política penal", é necessária a lição de CIRINO DOS SANTOS: "No Brasil e, de modo geral, nos países periféricos, a política criminal do Estado exclui políticas públicas de emprego, salário digno, escolarização, moradia, saúde e outras medidas complementares, como programas oficiais capazes de alterar ou reduzir as condições sociais adversas da população marginalizada do mercado de trabalho e dos direitos de cidadania, definíveis como determinações estruturais do crime e da criminalidade; por isso, o que deveria ser a política criminal do Estado existe, de fato, como simples política penal instituída pelo Código Penal e leis complementares - em última instância, a formulação legal do programa oficial de controle social do crime e da criminalidade: a definição de crimes, a aplicação de penas e a execução penal, como níveis sucessivos da política penal do Estado, representam a única resposta oficial para a questão criminal". (CIRINO DOS SANTOS, Juarez. Direito penal: parte geral. 2. ed. rev. atual. Curitiba: ICPC/Lúmen Juris, 2007, p. 453). 
Reduzida a política criminal à mera política penal, a legitimação do direito penal brasileiro gravita ao redor da idéia nuclear de pena ${ }^{29}$. Consequentemente, a repressão estatal depende da legitimação retórica oferecida pela teoria oficial da pena; se a sanção criminal é incapaz de resolver o problema do crime e da criminalidade, não há mais justificativa jurídica para existência do Direito Penal ${ }^{30}$.

O problema central do discurso ${ }^{31}$ oficial de legitimação da pena - e, portanto, do Direito Penal - é que atribui à pena criminal funções incompatíveis com a realidade de sua aplicação. O radical contraste entre as funções declaradas e a cruel tragédia da execução penal no Brasil coloca em xeque o discurso que autoriza a aplicação de penas em sociedades democráticas. E esse contraste não pode sequer ser atribuído à má implementação de uma política pública, pois as funções atribuídas à pena no Brasil sempre se caracterizaram como retórica ${ }^{32}$, nunca constituindo um projeto real na política penitenciária implementada pelo Estado.

${ }^{29}$ Segundo Gilberto FERREIRA, "a pena é a conseqüência jurídica - o mal que se impõe". (FERREIRA, Gilberto. A aplicação da pena. Rio de Janeiro: Forense, 2004, p. 4-5). O autor ainda lista na página anterior uma série de definições sobre o caráter da pena. Parece-me importante salientar que ele, acertadamente, escapa do erro conceitual ao qual se renderam a maioria dos autores, pois não confunde o conceito de pena com suas funções. Em oposição, comparar com JESUS, Damásio E. de. Direito penal. 8. ed. São Paulo: Saraiva, 1983, p. 475.

${ }^{30}$ CIRINO DOS SANTOS. Direito ..., p.453.

31 "Discurso" aqui se refere às manifestações retóricas oficiais que legitimam as ações repressivas do Estado contra o cidadão submetido. A partir de um local simbólico, o Estado estabelece sua argumentação tendo por auditório universal (o qual pretende convencer) o senso comum e como auditório particular (o qual pretende persuadir) a classe detentora dos meios de produção capitalista. Evidente, portanto, que raramente as razões (ou conviçcões) serão semelhantes às racionalizações (ou justificações) do discurso, pois os recursos argumentativos variam de acordo com os valores do auditório. Desta forma, o "Discurso do Poder" assemelha-se sobremaneira à Propaganda, pois não é porta-voz dos consensos sociais, mas uma forma de convencimento pela repetição e apelo emocional, divulgada por intermédio dos meios de comunicação e demais aparelhos ideológicos. Seu objetivo é atuar no convencimento e normalização até alcançar o custo de legitimação suficiente para determinadas ações políticas. Para o estudo desta importante área da lógica, e para compreensão das formas pelas quais se autoriza a aplicação simbólica da pena, imprescindível a leitura da obra PERELMAN, Chaïm; OLBRECHTS-TYTECA, Lucie. Tratado da argumentação: a nova retórica. Trad. Maria Ermantina Galvão. São Paulo: Martins Fontes, 2002.

32 "Os problemas do sistema penal são sempre conjunturais, e o melhor exemplo é a penitenciária. A despeito de todos os relatórios (...) apontarem para a irremediável deterioração do emprisionamento sobre sua clientela, de que as taxas de reincidência penitenciária são o menos expressivo sinal, a boa penitenciária nos aguarda, num futuro eternamente adiado". BATISTA, Nilo. Mídia e sistema penal no capitalismo tardio. Discursos sediciosos: crime, direito e sociedade. Rio de Janeiro, a. 7, n. 12, p. 274, 2002. 
O PROGRAMA DE POLÍTICA CRIMINAL BRASILEIRO: FUNÇÕES DECLARADAS E REAIS (CONTRIBUIÇÕES DE ClAUS OFFE PARA FUNDAMENTAÇÃo DA CRÍTICA CRIMINOLÓGICA À TEORIA JURÍDICA DAS PENAS)

Em que pese a realidade demonstrar a absoluta impossibilidade de realizar os fins declarados da pena, o que por si só já desautorizaria a intervenção penal pública, o discurso oficial adota a teoria unificada, e continua a afirmar que a pena criminal serve simultaneamente para reprovar o crime atual e prevenir futuros delitos ${ }^{33}$.

Para poder avançar na análise crítica da teoria jurídica das penas, tendo em vista o referente teórico, faz-se necessário apresentar sucintamente em que consistem essas funções de reprovação e prevenção atribuídas pelo poder político à execução da pena. Apresentada a fundamentação teórica tradicional, busca-se identificar os mais atuais contornos retóricos apresentados para cada uma dessas funções. Finalmente, cada uma destas funções é objeto de crítica criminológica.

\subsection{A PENA COMO REPROVAÇÃO DO CRIME}

Como visto, o Código Penal atribui à pena criminal a função de reprovação, doutrinariamente lida como retribuição e definida como o "mal justo" que deve ser aplicado ao "mal injusto" do crime ${ }^{34}$. Em poucas palavras, é o retrato jurídico da lei do talião. Em estritos termos dogmáticos, a retribuição é o critério que quantifica a duração da pena e qualifica sua intensidade, de acordo com a culpabilidade do agente $^{35}$.

A pena como retribuição é tão antiga como a história documentada da humanidade, mas suas justificações mais recentes são inspiradas na tradição moral

${ }^{33}$ Código Penal, Art. 59. "O juiz, atendendo à culpabilidade, aos antecedentes, à conduta social, à personalidade do agente, aos motivos, às circunstâncias e consequiências do crime, bem como ao comportamento da vítima, estabelecerá, conforme seja necessário e suficiente para reprovação e prevenção do crime: I - as penas aplicáveis dentre as cominadas; II - a quantidade de pena aplicável, dentro dos limites previstos; III - o regime inicial de cumprimento da pena privativa de liberdade; IV - a substituição da pena privativa de liberdade aplicada, por outra espécie de pena, se cabível".

${ }^{34}$ CIRINO DOS SANTOS, Juarez. Teoria de pena: fundamentos políticos e aplicação judicial. Curitiba: ICPC/Lumen Juris, 2005, p. 3.

${ }^{35}$ Ibidem, p. 3-5. 
cristã e na filosofia ocidental idealista; de qualquer modo, ontem como hoje, continua dependente de argumentação de referência metafísica.

A crítica em relação ao discurso retributivo não é recente; sua grande derrota como argumento legitimador da imposição de penas aconteceu pela mão dos "penalistas do contratualismo", que a expulsaram da ciência jurídica moderna para o ostracismo do conhecimento vulgar ${ }^{36}$. Todavia, como um aparente traço da psicologia popular de base antropológica, continua a povoar o senso comum como referencial para a pena, sendo no Brasil consagrada pela lei $^{37}$. Contemporaneamente a doutrina penal majoritária nega-lhe o caráter democrático e científico. Não é democrático porque nos Estados Democráticos de Direito o poder é exercido em nome do povo e não de qualquer autoridade metafísica; além disso, o Direito Penal não tem por objetivo oficial realizar vingança - seja ela pública ou privada - , mas proteger bens jurídicos. Da mesma forma, não é científico, porque aplicar "mal justo" suficiente e necessário para reprovar "mal injusto" pressupõe a demonstração cabal da liberdade humana, fato que é absolutamente improvável ${ }^{38}$.

\subsection{A PENA COMO POSSIBILIDADE DE PREVENIR FUTUROS CRIMES}

Além de retribuir o crime, o discurso jurídico afirma que é função da pena evitar a realização de novos crimes, caminho pelo qual se ingressa no campo da prevenção. Essa função preventiva é direcionada tanto para o indivíduo condenado quanto para a sociedade. No primeiro caso a dogmática penal define essa função de

${ }^{36}$ Expressão que pretende compreender todos os autores que, impregnados pela ideologia liberal, defendiam um direito penal humanitário, superando a idéia de retribuição pela prevenção como função precípua da pena criminal. $\mathrm{O}$ argumento central para estes autores é que a execução da pena deve ter como norte a utilidade, como se vê em ZAFFARONI, Eugenio Raúl; PIERANGELI, José Henrique. Manual de direito penal brasileiro: parte geral. 5. ed. rev. atual. São Paulo: RT, 2004, p. 251-264.

${ }^{37}$ CIRINO DOS SANTOS. Direito ..., p. 455-456.

${ }^{38}$ Ibidem, p. 457-458. 
O PROGRAMA DE POLÍTICA CRIMINAL BRASILEIRO: FUNÇÕES DECLARADAS E REAIS (CONTRIBUIÇÕES DE ClAUS OFFE PARA FUNDAMENTAÇÃo DA CRÍTICA CRIMINOLÓGICA À TEORIA JURÍDICA DAS PENAS)

prevenção especial e no segundo de prevenção geral, podendo em qualquer caso seguir um sentido positivo ou negativo, como se demonstra adiante.

O objetivo declarado dos modernos programas de política criminal é realizar todas as funções preventivas durante as diversas etapas da execução, e a prevenção constitui desde a Modernidade o ponto central de legitimação do Direito Penal, avaliado pela sua utilidade como instrumento de manutenção da ordem social.

Todas as funções preventivas apresentam uma concepção clássica, uma variante recente e uma crítica teórica específica, como a seguir se explicita.

3.2.1 A função de prevenir o condenado de praticar novos crimes (prevenção especial)

A prevenção especial é negativa quando tem por objetivo a "neutralização" do sujeito criminoso - ou melhor, criminalizado - do coletivo social pelo isolamento ${ }^{39}$, impedindo a prática de crimes fora dos limites da prisão ${ }^{40}$. Sua base teórica remonta à antiga criminologia etiológica, que identificava o crime como doença e o criminoso como elemento patogênico, sendo a pena a inocuização necessária para manter o corpo social saudável.

Atualmente, e após o abandono do argumento higienista, a justificativa para o isolamento de criminosos em presídios especiais ou pequenas celas incomunicáveis é, respectivamente, dificultar a organização de quadrilhas pela neutralização de seus líderes e evitar a corrupção dos agentes oficiais e o exercício arbitrário e violento das próprias razões no interior das instituições. A atualidade desse discurso é evidente, tendo sido utilizado para fundamentar a criação dos presídios federais de segurança

39 “A prevenção especial negativa de neutralização do criminoso, baseada na premissa de que a privação de liberdade do condenado produz segurança social, parece óbvia: a chamada incapacitação seletiva de indivíduos considerados perigosos constitui efeito evidente da execução da pena, porque impede a prática de crimes fora dos limites da prisão - e, assim, a neutralização do condenado seria uma das funções manifestas ou declaradas cumpridas pela pena criminal". CIRINO DOS SANTOS. Teoria ..., p. 7-8.

${ }^{40}$ Ibidem, p. 7. 
máxima e violação da lei de execuções penais pelo regime disciplinar diferenciado.

A função de prevenção especial negativa é objeto das seguintes críticas teóricas: pela perspectiva criminológica, rotular o criminoso como elemento patogênico de um corpo social saudável só é possível quando se confunde crime com doença, o que é impossível desde a constatação de que o crime é um fato social normal $^{41}$, quase que totalmente tolerado pela sociedade ${ }^{42}$; pela perspectiva jurídica é função incompatível com o texto constitucional, pois a segregação de um indivíduo só é autorizada na medida em que evita o livre deslocamento ambulatório, sendo as demais formas de expressão da liberdade individual inalteradas pela pena. Além disso, o uso de células solitárias para encarceramento caracteriza punição cruel, prática punitiva vedada pela Constituição.

A prevenção especial é dita positiva quando tem por fim a reeducação ou ressocialização $^{43}$ do detento pela execução da pena ${ }^{44}$. Essa função tem raízes na ideologia do tratamento ${ }^{45}$, que considera o criminoso um desviante capaz de ser corrigido por meio de técnicas corretivas da ortopedia moral ${ }^{46}$ do condenado.

O discurso da prevenção especial positiva vem gradualmente abandonando o propósito de reintegração do condenado por meio da capacitação para o trabalho em

${ }^{41}$ Como já havia antecipado a sociologia de Émile Durkheim. Sobre as derivações teóricas criminológicas a partir desse pressuposto, especialmente em Robert Merton, imprescindível a lição de BARATTA, Alessandro. Criminologia crítica e crítica do direito penal. Rio de Janeiro: Freitas Bastos, 1999, p. 60-62.

${ }^{42}$ Como constatado pelo estudo sobre a "cifra negra" da criminalidade. Em apresentação preliminar sobre o tema, vale a excelente lição de HASSEMER, Winfried; CONDE, Francisco Muñoz. Introducción a la criminologia. Valencia (Espanha): Tirant lo Blanch, 2001, p. 136-148.

${ }^{43}$ A prevenção especial positiva é a principal função atribuída à pena no discurso oficial atual, e está formalmente prevista no artigo $1^{\circ}$ da Lei de Execuções Penais: "Art. $1^{\circ}$ A execução penal tem por objetivo efetivar as disposições de sentença ou decisão criminal e proporcionar condições para a harmônica integração social do condenado e do internado".

44 “(...) a prevenção especial positiva de correção (ou de ressocialização, ou de reeducação etc.) do criminoso, realizada pelo trabalho de psicólogos, assistentes sociais e outros funcionários da ortopedia moral do estabelecimento penitenciário, durante a execução da pena - segundo outra fórmula antiga: punitur, ne peccetur". CIRINO DOS SANTOS. Teoria ..., p. 7.

${ }^{45}$ CIRINO DOS SANTOS, Juarez. Direito ..., p. 478.

46 Expressão de FOUCAULT, Michel. Vigiar e punir: nascimento da prisão. 26. ed. Petrópolis: Vozes, 2002, p. 238-239. 
O PROGRAMA DE POLÍTICA CRIMINAL BRASILEIRO: FUNÇÕES DECLARADAS E REAIS (CONTRIBUIÇÕES DE CLAUS OFFE PARA FUNDAMENTAÇÃo DA CRÍTICA CRIMINOLÓGICA À TEORIA JURÍDICA DAS PENAS)

direção à tese que propõe o deslocamento da lógica de mercado para o interior dos presídios, delegando sua administração para a iniciativa privada, com o duplo propósito de desonerar o poder público e dar utilidade à força de trabalho encarcerada.

A crítica à vertente positiva da prevenção especial é bastante fácil, pois constitui um dos argumentos mais falaciosos de justificação da pena. A própria idéia de ressocialização pelo isolamento e reeducação em ambiente desumano é paradoxal. Especialmente em países periféricos, a justificação da pena pela prevenção especial positiva é insustentável diante das terríveis condições das penitenciárias, absolutamente incapazes de instituir um programa mínimo de ressocialização. Mesmo assim, e graças aos contornos modernos da política penal neoliberal, o Estado tem delegado a administração de alguns presídios para empresas privadas, apresentando reiteradamente estas instituições como experiências bem-sucedidas.

3.2.2 A função de prevenir que a sociedade se motive no crime alheio (prevenção geral)

Em sua forma negativa, a prevenção geral funcionaria como inibidora de futuras ações criminosas pela certeza da punição, realçando-se o poder intimidante que caracteriza o Direito Penal na consciência coletiva. Assim como a função de retribuição, o discurso da prevenção geral negativa continua a ser apresentado com poucas alterações, sustentado pela falsa premissa de que a crueldade da execução penal é suficiente para desmotivar o criminoso potencial. Este é o argumento que parece justificar a precariedade dos presídios no Brasil, seguindo a lógica de que as condições de vida da prisão têm que ser piores do que as piores condições da classe trabalhadora $^{47}$. Sua atualidade também é evidente quando se propõe o recrudescimento das penas previstas e sua execução como forma de evitar novos crimes.

${ }^{47}$ RUSCHE, Georg; KIRCHHEIMER, Otto. Punição e estrutura social. Trad. Gizlene Neder. Rio de Janeiro: Freitas Bastos, 1999, p. 16-20. 
A análise crítica demonstra que prevenção geral negativa é absolutamente ineficaz em seu efeito intimidante, o que fica bastante evidente em uma sucinta análise histórica que compreenda o horror da execução penal medieval ${ }^{48}$. Em termos jurídicos, a falta de um critério limitador para o uso da pena como intimidação torna absolutamente injusta sua execução, provocando uma necessária violação da dignidade do condenado ${ }^{49}$, fato inevitável, pois inerente à estratégia de controle social pelo medo ${ }^{50}$.

Por outro lado, a prevenção geral em sua forma positiva cumpriria o papel de normalizar as relações sociais, garantindo a ordem através da estabilização das expectativas comportamentais normativas. Sua formulação é bastante recente, identificada na doutrina alemã do final do século XX, e tem por base uma recente construção sociológica. Por constituir o mais novo recurso argumentativo legitimador da pena ${ }^{51}$ é oportuna sua explicitação mais detalhada. Referida construção teórica tem como elemento condutor as premissas sociológicas de Niklas LUHMANN, que propõe a partir da teoria dos sistemas $^{52}$ uma abordagem que despersonifica a análise sociológica $^{53}$. Sob esta ótica, o Direito é visto como um redutor da ampla contingência

${ }^{48}$ Ibidem, p. 24-28 e FOUCAULT, op. cit., p. 49-101.

${ }^{49}$ CIRINO DOS SANTOS. Direito ..., p. 461.

50 "Essa crítica relativizou a teoria e colocou em discussão outra de maior entidade, de acordo com a qual a prevenção intimidatória lesiona a dignidade do homem enquanto utiliza a pessoa, como meio para a intimidação de outra e, ademais, não é crível em seus efeitos reais, posto que parte de suposições tão difíceis de satisfazer como o conhecimento por parte de todos os cidadãos, das sanções penais e das condenações, e da motivação dos cidadãos honrados pela cominação e execução penal”. GARCÍA, Olga Lucia Gaitán. Direito penal contemporâneo: da tutela pena a uma lesão à proteção de riscos. Discursos sediciosos: crime, direito e sociedade, Rio de Janeiro, a. 7, n. 12, p. 43, 2002.

${ }^{51}$ Em que pese a advertência de teóricos críticos de que essa hipótese que não possui elementos inéditos, como demonstra CIRINO DOS SANTOS: “(...) HEGEL (1770 - 1831) define crime como negação do direito e pena como negação da negação e, portanto, como reafirmação do direito - uma antecipação de dois séculos da prevenção geral positiva de JAKOBS, da pena como afirmação da validade da norma (...)". CIRINO DOS SANTOS. Teoria ..., p. 5.

${ }^{52}$ Cf. VIANNA, Túlio Lima. Da ditadura dos sistemas sociais: uma crítica à concepção de direito como sistema autopoiético. Revista Crítica Jurídica, Curitiba, n. 22, p. 67-72, jul./dez. 2003.

53 "Para Luhmann a sociedade é um sistema autopoiético cuja organização sustenta-se na comunicação. A sociedade até então concebida como o conjunto de indivíduos, passa a ser tratada como um sistema que tem como elemento a informação e como organização a comunicação (...) Notese que, na teoria de Luhmann, os seres humanos somos mero ambiente na sociedade". VIANNA, $o p$. 
O PROGRAMA DE POLÍTICA CRIMINAL BRASILEIRO: FUNÇÕES DECLARADAS E REAIS (CONTRIBUIÇÕES DE ClAUS OFFE PARA FUNDAMENTAÇÃo DA CRÍTICA CRIMINOLÓGICA À TEORIA JURÍDICA DAS PENAS)

das ações individuais ${ }^{54}$, a quem cabe uma realizar uma seletividade específica ${ }^{55}$.

Esta Sociologia do Direito, baseada na abordagem estruturalista ${ }^{56}$ e sistêmica $^{57}$, projeta-se para o Direito Penal com graves conseqüências. Ao preferir a proteção de valores sociais abstratamente definidos em detrimento à responsabilização pessoal e proporcional à lesão real, torna a manutenção das "expectativas sociais" o objetivo principal da pena criminal $^{58}$ : a ilusão de segurança jurídica se sobrepõe à efetiva proteção de direitos fundamentais.

Assim, para todos os casos de violação de bens jurídicos aos quais a mídia dedica-se com particular entusiasmo e cuja conseqüência é a inevitável reação popular

cit., p. 73.

54 "O direito é visto, então, como uma estrutura que define os limites e as interações da sociedade. Como estrutura, ele é indispensável, por possibilitar uma estabilização de expectativas nas interações. Ele funciona como um mecanismo que neutraliza a contingência das ações individuais, permitindo que cada ser humano possa esperar, com um mínimo de garantia, o comportamento do outro e vice-versa". FERRAZ JR., Tércio Sampaio. Apresentação. In: LUHMANN, Niklas. Legitimação pelo procedimento. Brasília: UnB, 1980, p. 1.

55 “(...) a função do direito reside em sua eficiência seletiva, na seleção de expectativas comportamentais que possam ser generalizadas em todas as três dimensões, e essa seleção, por seu lado, baseia-se na compatibilidade entre determinados mecanismos das generalizações temporal, social e prática (...) e podemos agora definir o direito como estrutura de um sistema social que se baseia na generalização congruente de expectativas comportamentais normativas". LUHMANN, Niklas. Sociologia do direito. Trad. Gustavo Bayer. Rio de Janeiro: Tempo Brasileiro, 1983. v. 1, p. 116

${ }^{56}$ Como esclarece YAROCHEWSKY, "segundo Niklas Luhmann, o sistema jurídico é um subsistema do sistema social global de um sistema unitário e a função do direito deve ser compreendida diante das expectativas, ou seja, da manutenção e da estabilidade de determinadas expectativas, tendo em vista as decepções previsíveis e inevitáveis. As expectativas têm como função orientar de modo relativamente estável a comunicação e o pensamento diante da complexidade e contingência do mundo". YAROCHEWSKY, Leonardo Isaac. A influência da teoria dos sistemas de Niklas Luhmann na teoria da pena. Ciências Penais: Revista da Associação Brasileira de Professores de Ciências Penais, São Paulo, a. 1, n. 00, p. 294, 2004.

57 "Sistema é para Luhmann um conjunto de elementos delimitados segundo o princípio da diferenciação. Os elementos, ligados uns aos outros, excluem outros elementos do seu convívio, formam em relação a estes, um conjunto diferenciado. Todo sistema pressupõe, portanto, um mundo circundante com o qual se limita. O mundo é, por hipótese, o que não pertence ao sistema. Ora, se o sistema é um conjunto estruturado, o mundo é, em relação a ele, complexidade, isto é, um conjunto aberto e infinito de possibilidades. Ou seja, todo sistema é uma redução seletiva de possibilidades em comparação com as possibilidades infinitas do mundo circundante (...) Aquilo que garante o sistema contra a contingência das possibilidades escolhidas é a estrutura do sistema”. FERRAZ JR., op. cit., p. 3.

58 "Normas, segundo Luhmann, garantem as expectativas (mas não o comportamento correspondente) contra desilusões". Ibidem, p. 2. 
exigindo punições, o magistrado convertido em responsável por reestabilizar a "paz social", vê-se - no mínimo - inclinado ou - no máximo - moralmente obrigado a condenar o(s) réu(s) destes casos que mais afetam a consciência coletiva, pois caso contrário estaria frustrando as expectativas da sociedade, causando um desequilíbrio na ordem social e uma desconfiança geral nas instituições ${ }^{59}$. Converte-se, consoante esta lógica, o réu em "inimigo da ordem”, e a possibilidade ou intensidade da punição não é mais definida pelas categorias analíticas do fato punível ${ }^{60}$, mas pela necessidade de reafirmação das instituições do poder oficial. A mudança é evidente: não é mais avaliado o caso concreto, apenas ponderado o perigo (em abstrato) que uma decisão possa causar nas estruturas políticas; protege-se o modelo (a ordem vigente) antes das garantias cidadãs ${ }^{61}$.

Autores contemporâneos não têm poupado críticas a prevenção geral positiva. De forma geral, pode-ser afirmar que os doutrinadores concluem que o Direito Penal como instrumento para manutenção destas expectativas é retributivo e injusto, ao permitir que os princípios garantistas sejam desconsiderados em nome do imediatismo da sanção penal. Em países subdesenvolvidos a adoção da prevenção geral positiva tem como conseqüência o aumento da clivagem entre a sociedade de consumo e a coletividade marginalizada, pois fortalece e antecipa os mecanismos de repressão social dos Estados comprometidos com o capital industrial e financeiro internacional.

Se as funções manifestas da pena, decorrentes das funções atribuídas ao Direito Penal, não são realizadas pela justiça criminal, é necessário agora definir quais

59 "A manutenção de uma parcela de seres humanos absolutamente marginalizada, em condições sociais miseráveis, seria perfeitamente lícita desde que não prejudicasse a autopoiese do sistema”. VIANNA, op. cit., p. 75.

${ }^{60}$ Entre elas, especialmente a culpabilidade como garantia retórica do cidadão face ao poder punitivo do Estado.

61 Como aponta Jakobs "Certamente, é possível que se vinculem à pena determinadas esperanças de que se produzam conseqüências psicológicas sociais ou individuais das mais variadas características, como, por exemplo, a esperança de que se mantenha ou solidifique a fidelidade ao ordenamento jurídico". Tradução livre de: "Ciertamente, puede que se vinculen a la pena determinadas esperanzas de que se produzcan consecuencias de psicología social o individual de muy variadas características como, por ejemplo, la esperanza de que se mantenga o solidifique la fidelidad al ordenamiento jurídico". JAKOBS, Günther. Sociedad, norma, persona, en una teoría de un derecho penal funcional. Apud. YAROCHEWSKY, op. cit., p. 295. 
O PROGRAMA DE POLÍTICA CRIMINAL BRASILEIRO: FUNÇÕES DECLARADAS E REAIS

(CONTRIBUIÇÕES DE ClAUS OFFE PARA FUNDAMENTAÇÃo DA CRÍTICA CRIMINOLÓGICA À TEORIA JURÍDICA

DAS PENAS)

são as funções reais cumpridas pela criminalização secundária ${ }^{62}$ no Brasil.

\subsection{AS VERDADEIRAS FUNÇÕES DA PENA: UMA REFLEXÃO A PARTIR DA CRIMINOLOGIA RADICAL}

Dadas as funções declaradas da pena pelo discurso oficial, bem como seu fracasso institucional - em contraste com seu relativo sucesso retórico -, torna-se necessário refletir sobre as funções reais da pena, as quais, longe de constituírem uma teoria improvável de matizes subversivos, "saltar-vos-á ao rosto não tarda",63.

Para a teoria crítica, o direito penal é uma técnica de controle social ${ }^{64}$. Como mecanismo estatal de dominação de $\operatorname{classe}^{65}$, seu objetivo final é a manutenção da

62 “(...) a criminalização secundária e a ação punitiva exercida sobre pessoas concretas, que ocorre quando as agências policiais detectam uma pessoa, à qual atribuem a realização de certo ato criminalizado primariamente, investigam-na, em alguns casos privam-na de sua liberdade de locomoção, submetem-na à agência judicial, a qual por sua vez legitima a atuação anterior, admite um processo (ou seja, o avanço de uma série de atos secretos ou públicos para determinar se realmente realizou essa ação), discute publicamente se o sujeito a realizou e, em caso afirmativo, admite a imposição de uma pena de certa magnitude que, sendo privativa de liberdade de locomoção, executase em uma penitenciária (prisionalização)”. Tradução livre de “(...) la criminalización secundaria es la acción punitiva ejercida sobre personas concretas, que tiene lugar cuando las agencias policiales detectan a una persona, a la que se atribuye la realización de cierto acto criminalizado primariamente, la investiga, en algunos casos la priva de su libertad ambulatoria, la somete a la agencia judicial, ésta legitima lo actuado, admite un proceso (o sea, el avance de una serie de actos secretos o públicos para establecer si realmente ha realizado esa acción), se discute públicamente si la ha realizado y, en caso afirmativo, admite la imposición de una pena de cierta magnitud que, cuando es privativa de la libertad ambulatoria de la persona, es ejecutada por una agencia penitenciaria (prisionización)." ZAFFARONI, Eugenio Raul; ALAGIA, Alejandro; SLOKAR, Alejandro. Derecho penal: parte general. 2. ed. Buenos Aires: Ediar, 2002, p. 7.

${ }^{63}$ Parafraseando a expressão utilizada por SARAMAGO no encerramento do II Fórum Social Mundial pretende-se não apenas enriquecer o presente artigo pela inserção de uma metalinguagem da melhor literatura lusitana, mas lembrar que, assim como no conto do escritor português sobre a morte da Justiça no pequeno vilarejo de Florença, também é necessário anunciar a morte do discurso oficial legitimador da pena, por meio das badaladas dos sinos libertadores da Criminologia Radical. O sentido completo deste excerto pode ser conotado a partir do excelente conto do escritor português. SARAMAGO, José. Da justiça à democracia, passando pelos sinos. In: Cadernos do Terceiro Mundo, Porto Alegre, n. 239, 2002.

${ }^{64}$ BATISTA, op. cit., p. 21.

${ }^{65}$ Ainda que se refira à época posterior à Revolução Industrial, mutatis mutandis é válida a lição da Criminologia Radical: "O Estado, produto do antagonismo irreconciliável de classes, 
ordem econômica pela gestão diferencial da criminalidade ${ }^{66}$. A pena, como instrumento mais rigoroso para garantir a existência e continuidade desse sistema, explicita a função real de controle social do direito penal, deslocando a função declarada de proteção a direitos fundamentais para um lugar subsidiário, fragmentário ou meramente ilusório $^{67}$.

Ainda como premissa da análise crítica radical, existiria uma relação direta entre as formas de punição estabelecidas pelo poder institucional e as demandas do modelo econômico de uma sociedade ${ }^{68}$. Como esclarece a análise histórica, essa relação determina que as penas sejam aplicadas e executadas de acordo com a utilidade do condenado no modo de produção vigente. Para compreender esse fenômeno não é suficiente estudar o discurso técnico-jurídico da pena criminal, dado seu objetivo permanente de justificar e ocultar essa relação ${ }^{69}$; é mister alargar o campo de pesquisa histórico para buscar, na dinâmica específica do espaço social e econômico, os fundamentos dessa relação ${ }^{70}$.

Como resultado, a Criminologia $\operatorname{Radical}^{71}$ rompe com a ilusão das funções

representa uma força especial de repressão, ou a organização sistemática da violência, para a opressão de uma classe sobre a outra: as classes economicamente dominantes, utilizando o poder concentrado dos aparelhos coercitivos (polícia, prisão, forças armadas), garantem a dominação política e a exploração econômica das classes dominadas, controlando os antagonismos de classe nos limites da ordem burguesa". CIRINO DOS SANTOS, Juarez. A criminologia radical. Rio de Janeiro: Forense, 1981, p. 64.

${ }^{66}$ Ibidem, p. 57.

${ }^{67}$ CIRINO DOS SANTOS. Direito ..., p. 4-14.

${ }^{68}$ RUSCHE; KIRCHHEIMER, op. cit., p. 18-21.

${ }^{69}$ Seguindo o método de FOUCAULT de "considerar as práticas penais mais como um capítulo da anatomia política, do que uma consequiência das teorias jurídicas". FOUCAULT, op. cit., p. 28.

70 HESPANHA, António Manuel. Cultura jurídica européia: síntese de um milénio. Florianópolis: Fundação Boiteux, 2005, p. 38.

${ }^{71}$ A Criminologia Radical demonstra, por meio dos pressupostos marxistas, a explicação materialista dos objetivos do sistema penal na intenção de perpetuar as relações de poder. A contribuição do marxismo para a instrumentalização das ciências é necessária em qualquer abordagem crítica, como indica KONDER: "O marxismo (...) oferece aos produtores de cultura poderosos instrumentos para que estes submetam suas próprias contradições a uma análise libertadora, mas cobra deles a humildade de renunciarem às fantasias idealistas de supervalorização de si mesmos e intima-os a verem no trabalho em que se empenham com todas as suas energias apenas um momento do movimento transformador das sociedades. Com seu materialismo histórico, (...) mostra os limites 
O PROGRAMA DE POLÍTICA CRIMINAL BRASILEIRO: FUNÇÕES DECLARADAS E REAIS (CONTRIBUIÇÕES DE ClAUS OFFE PARA FUNDAMENTAÇÃo DA CRÍTICA CRIMINOLÓGICA À TEORIA JURÍDICA DAS PENAS)

declaradas da pena, evidenciando a necessária conexão entre as relações de poder determinadas pela distribuição desigual dos meios de produção e pela sujeição mediante trabalho assalariado e a política penal do Estado. Explicita, pela visão marxista, uma explicação materialista para o papel desempenhado pela pena na intenção de perpetuar as relações de poder:

O objetivo real mais geral do sistema de justiça criminal (além da aparência ideológica e da consciência honesta de seus agentes) é a moralização da classe trabalhadora, através da inculcação de uma 'legalidade de base': o aprendizado das regras da propriedade, a disciplina no trabalho produtivo, a estabilidade no emprego, na família, etc. A utilidade complementar da constituição de uma 'criminalidade de repressão' (localizada nas camadas oprimidas da sociedade e objeto de reprodução institucional) é camuflar a criminalidade dos opressores (abuso de poder político e econômico), com a tolerância das leis, a indulgência dos tribunais e a discrição da imprensa. ${ }^{72}$

O mercado de trabalho, determinante dos sistemas de punição adotado pelo Estado é determinado pela seguinte lógica: "se a força de trabalho é insuficiente para as necessidades do mercado, o sistema penal adota métodos punitivos de preservação da força de trabalho; se a força de trabalho excede as necessidades do mercado, o sistema penal adota métodos punitivos de destruição da força de trabalho"73.

Estabelece-se desta forma a função da pena sob o princípio da retribuição equivalente, uma característica essencial da estrutura material das relações econômicas fundadas no capitalismo ${ }^{74}$.

A pena - e em especial a pena privativa de liberdade - serve perfeitamente à manutenção da sujeição inerente ao sistema de produção pós-industrial, o qual é historicamente fundado no binômio prisão-fábrica: fábrica para aqueles que são adequados às condições impostas - como grau de instrução, submissão etc. - e prisão

desse momento, ensinando que os problemas mais profundos da luta que os intelectuais e artistas travam no plano da cultura têm sua efetiva solução encaminhada num outro plano, que é o das mudanças diretamente sócio-econômicas, isto é, o da transformação das relações de produção". KONDER, Leandro. Introdução ao fascismo. Rio de Janeiro: Graal, 1977, p. 40.

${ }^{72}$ CIRINO DOS SANTOS. A Criminologia ..., p. 58.

${ }^{73}$ CIRINO DOS SANTOS. Teoria ..., p. 20. 
para aqueles que não são úteis ao capital ${ }^{75}$.

Desta forma, a verdadeira função resume-se a reproduzir as relações sociais de dominação de classe, o que ocorre de três modos: pela retribuição (determinada pelo tempo de contingência do indivíduo), pela prevenção especial (disciplinando o condenado na ideologia oficial) ${ }^{76}$ e pela prevenção geral (pela preservação da ordem social fundada na relação capital - trabalho $)^{77}$.

Ainda que evidentes, as funções reais da pena não são apresentadas na doutrina tradicional do Direito Penal. Em regra, o estudo da pena é reduzido ao engodo de suas funções declaradas, uma cantilena hipócrita do discurso repressivo repetida pela dogmática conivente, salvo raras e brilhantes exceções ${ }^{78}$.

\section{CONSIDERAÇÕES FINAIS: A CONVERGÊNCIA DE SENTIDO ENTRE AS CONCLUSÕES DA CRIMINOLOGIA CRÍTICA E A PROPOSTA TEÓRICA DE CLAUS OFFE}

Seguindo as conclusões de OFFE, a intervenção penal definida pelo programa de política criminal é uma ação estatal; portanto, simultaneamente seletiva e oculta. $\mathrm{O}$ crime, como ação contrária aos interesses capitalistas globais - definidos pela atividade de regulação - tem como resposta oficial a repressão, uma atividade estatal

${ }^{74}$ Ibidem, p. 21.

${ }^{75}$ MELOSSI, Dario; PAVARINI, Massimo. Cárcel y fábrica: los orígenes del sistema penitenciario. Madri: Siglo XXI, 1980, p. 44.

76 "A história das transformações do sistema penal, na perspectiva da relação entre base econômica e mecanismos superestruturais de controle, de Rusche a Kirchheimer, representa um avanço real da teoria criminológica radical: são as relações do mercado de trabalho, no período capitalista, que explicam a generalização da prisão como método de controle e disciplina das relações de produção (fábrica) e de distribuição (mercado), com o objetivo de formar um novo tipo humano: a força de trabalho necessária e adequada ao aparelho produtivo". CIRINO DOS SANTOS. A Criminologia ..., p. 43.

${ }^{77}$ Conforme CIRINO DOS SANTOS. Teoria ..., p. 23.

${ }^{78}$ Como são exemplos CIRINO DOS SANTOS. Teoria..., op. cit.; FOUCAULT, op. cit. e MELOSSI; PAVARINI, op. cit. 
O PROGRAMA DE POLÍTICA CRIMINAL BRASILEIRO: FUNÇÕES DECLARADAS E REAIS (CONTRIBUIÇÕES DE ClAUS OFFE PARA FUNDAMENTAÇÃo DA CRÍTICA CRIMINOLÓGICA À TEORIA JURÍDICA DAS PENAS)

marcada pela seletividade.

Mas identificar os fins reais da pena criminal não é uma tarefa fácil, porque a contínua redefinição teórica dos fins declarados da pena buscam, a todo o momento, justificar a execução penal no Brasil. Os objetivos de ressocializar e neutralizar o indivíduo, ou revalidar a confiança normativa e intimidar a população são "nãoacontecimentos" sistematicamente garantidos. Dessa forma, a práxis do discurso oficial da pena torna evidente o objetivo real da intervenção penal em países periféricos.

Pelo discurso oficial, o predomínio do interesse capitalista na aplicação das penas é realizado sem tornar-se evidente. O programa de política criminal oculta o programa capitalista de criminalização diferencial, e a teoria oficial da pena justifica a realização de suas funções reais.

A orientação capitalista que determina a seletividade dessa ação atribui à pena as funções de manutenção da distribuição desigual dos meios de produção, aplicando a pena de acordo com a utilidade do sujeito condenado: sujeitos inúteis ao sistema capitalista são aglomerados em depósitos humanos, que devem oferecer condições de vida inferiores à da classe mais pobre.

A teoria jurídica das penas, como teoria oficial apresentada pelo programa de política penal, é apenas uma forma de escamotear as funções reais da pena. Isso porque é insustentável em um Estado Democrático de Direito um programa de política criminal que assume o cárcere como instrumento de manutenção da estrutura de classes, como evidenciou a Criminologia Radical ${ }^{79}$. O uso do Direito Penal como instrumento para "gestão penal da pobreza" 80 não deve ser evidente. Assim, a teoria oficial da pena disfarça a criminalização desigual de sujeitos marginalizados. A seletividade penal é legalmente legitimada, justificando a realização de um controle penal diferenciado sob a égide do discurso preventivo e retributivo.

\footnotetext{
${ }^{79}$ A gênese e síntese desse pensamento em CIRINO DOS SANTOS. A Criminologia..., op.
} cit.

${ }^{80}$ WACQÜANT, Loïc. Punir os pobres: a nova gestão da miséria nos Estados unidos. Rio de 
Evidente que a insistência do Estado em projetos políticos destinados ao fracasso provoca conflitos, que podem repercutir na base de sua própria legitimidade. Por isso, ainda que permaneçam essencialmente inalteradas em seus fundamentos teóricos, oscilando entre retribuição e prevenção, as funções formais da pena estão em contínua redefinição. A disparidade explícita entre as funções declaradas da pena e a realidade de sua execução obriga o Direito Penal a oferecer novas formas de legitimação desta idéia fundamental para a manutenção da ordem social.

A absurda distância entre os fins declarados da pena e a execução do penal no Brasil gera dissonâncias, que resultam em uma crise de legitimidade da atividade estatal. Mas os ruídos provocados pela radical disparidade são silenciados por um sistema de propaganda absolutamente incorporado pela mídia nacional, que logra o apoio popular para a punição cruel pelo medo, e por uma contínua redefinição teórica da dogmática penal. A implementação da dominação de classe é garantida mesmo diante do sistema carcerário nacional, diminuindo pelo discurso penal ou pela propaganda o impacto e a freqüência das reclamações.

Sob essa perspectiva é possível concluir que o fracasso da execução da pena em relação aos objetivos a ela atribuídos pelo discurso oficial não demonstra a incapacidade do poder público, mas evidencia uma política bem sucedida de controle social, cujos objetivos são definidos pelos interesses capitalistas. Para realizar essa função, a teoria jurídica da pena serve para ocultar os objetivos reais do programa de política penal do Estado, os quais seguem uma orientação estrutural determinada pela utilidade do sujeito no sistema econômico, com o propósito de perpetuar as relações de poder definidas pela distribuição desigual dos modos de produção.

Janeiro: Freitas Bastos, 2001, p. 27-37. 
O PROGRAMA DE POLÍTICA CRIMINAL BRASILEIRO: FUNÇÕES DECLARADAS E REAIS

(CONTRIBUIÇÕES DE CLAUS OFFE PARA FUNDAMENTAÇÃO DA CRÍTICA CRIMINOLÓGICA À TEORIA JURÍDICA DAS PENAS)

\section{REFERÊNCIAS}

BARATTA, Alessandro. Criminologia crítica e crítica do direito penal. Rio de Janeiro: Freitas Bastos, 1999.

. Funções instrumentais e simbólicas do direito penal: lineamentos de uma teoria do bem jurídico. Revista Brasileira de Ciências Criminais, São Paulo, a. 2, 1984.

BATISTA, Nilo. Mídia e sistema penal no capitalismo tardio. Discursos sediciosos: crime, direito e sociedade. Rio de Janeiro, a. 7, n. 12, 2002.

BRANDÃO, Cláudio. Introdução ao direito penal. Rio de Janeiro: Forense, 2002.

CHOMSKY, Noam. Para entender o poder: o melhor de Noam Chomsky. Trad. Eduardo Francisco Alves. Rio de Janeiro: Bertrand Brasil, 2005.

CIRINO DOS SANTOS, Juarez. A criminologia radical. Rio de Janeiro: Forense, 1981.

Anatomia de uma criminologia crítica. In: BARATTA, Alessandro. Criminologia crítica e crítica do direito penal: introdução à sociologia do direito penal. 2. ed. Rio de Janeiro: Freitas Bastos, 1999.

. Direito penal: parte geral. 2. ed. rev. atual. Curitiba: ICPC/LumenJuris, 2007.

Teoria de pena: fundamentos políticos e aplicação judicial. Curitiba: ICPC/Lumen Juris, 2005.

DE GIORGI, Raffaele. A contingência da crítica e a artificialidade do direito. Conferência proferida em agosto de 1998 na Faculdade de Direito da Universidade Federal do Paraná.

FOUCAULT, Michel. Vigiar e punir: nascimento da prisão. 26. ed. Petrópolis: Vozes, 2002.

FERRAJOLI, Luigi. A pena em uma sociedade democrática. Discursos sediciosos: crime, direito e sociedade, Rio de Janeiro, a. 7, n. 12, 2002.

FERRAZ JR., Tércio Sampaio. Apresentação. In: LUHMANN, Niklas. Legitimação pelo procedimento. Brasília: UnB, 1980.

FERREIRA, Gilberto. A aplicação da pena. Rio de Janeiro: Forense, 2004.

FRAGOSO, Heleno Cláudio. Lições de direito penal. 7. ed. Rio de Janeiro: Forense, 1985.

GARCÍA, Olga Lucia Gaitán. Direito penal contemporâneo: da tutela pena a uma lesão à proteção de riscos. Discursos sediciosos: crime, direito e sociedade, Rio de Janeiro, a. 7, n. 12, 2002.

GLASSNER, Barry. Cultura do medo. São Paulo: Francis, 2003.

HASSEMER, Winfried; CONDE, Francisco Muñoz. Introducción a la criminologia. Valencia (Espanha): Tirant lo Blanch, 2001. 
HESPANHA, António Manuel. Cultura jurídica européia: síntese de um milénio. Florianópolis: Fundação Boiteux, 2005.

HIRSCHE, Joachim. Qué significa Estado? Reflexiones acerca de la teoria del Estado capitalista. Revista de Sociologia e Política, Curitiba, n 24, p. 165-175, jun. 2005.

JAKOBS, Günther. Ciência do direito e ciência do direito penal. Barueri: Manole, 2003.

; CANCIO-MELIÁ, Manuel. Derecho penal del enemigo. Madri: Civitas, 2003.

Fundamentos do direito penal. São Paulo: RT, 2003.

JESUS, Damásio E. de. Direito penal. 8. ed. São Paulo: Saraiva, 1983.

KONDER, Leandro. Introdução ao fascismo. Rio de Janeiro: Graal, 1977.

LUHMANN, Niklas. Legitimação pelo procedimento. Brasília: UnB, 1980.

O enfoque sociológico da teoria e prática do direito. Trad. Cristiano Paixão, Daniela Nicola e Samantha Dobrowolski. Revista Seqüência, Florianópolis, p. 16-29, jun. 1994. 1983. v. 1.

Sociologia do direito. Trad. Gustavo Bayer. Rio de Janeiro: Tempo Brasileiro,

MELOSSI, Dario; PAVARINI, Massimo. Cárcel y fábrica: los orígenes del sistema penitenciario. Madri: Siglo XXI, 1980.

MONTEIRO DE BARROS, Flávio Augusto. Direito penal. São Paulo: Saraiva, 1999. v. 1: parte geral.

OFFE, Claus. Problemas estruturais do Estado capitalista. Rio de Janeiro: Tempo Brasileiro, 1984.

PERELMAN, Chaïm; OLBRECHTS-TYTECA, Lucie. Tratado da argumentação: a nova retórica. Trad. Maria Ermantina Galvão. São Paulo: Martins Fontes, 2002.

POULANTZAS, Nicos. Problemas atuais da pesquisa marxista sobre o Estado. In: SILVEIRA, Paulo [org.]. Grandes cientistas sociais. São Paulo: Ática, 1984. p. 61-77. (n. 47)

PRADO, Luiz Regis. Curso de direito penal brasileiro. São Paulo: Revista dos Tribunais, 2000.

RIPOLLÉS, José Luis Díez. O direito penal simbólico e os efeitos da pena. Ciências Penais: Revista da Associação Brasileira de Professores de Ciências Penais, São Paulo, a. 1, n.00, 2004.

RUSCHE, Georg; KIRCHHEIMER, Otto. Punição e estrutura social. Trad. Gizlene Neder. Rio de Janeiro: Freitas Bastos, 1999.

SARAMAGO, 7José. Da justiça à democracia, passando pelos sinos. In: Cadernos do Terceiro Mundo, Porto Alegre, n. 239, 2002.

TAVARES, Juarez. Teoria do injusto penal. Belo Horizonte: Del Rey, 2000. 
O PROGRAMA DE POLÍTICA CRIMINAL BRASILEIRO: FUNÇÕES DECLARADAS E REAIS (CONTRIBUIÇÕES DE ClAUS OFFE PARA FUNDAMENTAÇÃo DA CRÍTICA CRIMINOLÓGICA À TEORIA JURÍDICA DAS PENAS)

VIANNA, Túlio Lima. Da ditadura dos sistemas sociais: uma crítica à concepção de direito como sistema autopoiético. Revista Crítica Jurídica, Curitiba, n. 22, p. 67-78, jul./dez. 2003.

YAROCHEWSKY, Leonardo Isaac. A influência da teoria dos sistemas de Niklas Luhmann na teoria da pena. Ciências Penais: Revista da Associação Brasileira de Professores de Ciências Penais, São Paulo, a. 1, n. 00, 2004.

WACQÜANT, Loïc. Punir os pobres: a nova gestão da miséria nos Estados unidos. Rio de Janeiro: Freitas Bastos, 2001.

WEBER, Max. Economia e sociedade. Brasília: UnB/São Paulo: Imprensa Oficial, 2004. v. 2.

ZAFFARONI, Eugenio Raul; ALAGIA, Alejandro; SLOKAR, Alejandro. Derecho penal: parte general. 2. ed. Buenos Aires: Ediar, 2002. . Em busca das penas perdidas. Rio de Janeiro: Revan, 1991. ; PIERANGELI, José Henrique. Manual de direito penal brasileiro: parte geral. 5. ed. rev. atual. São Paulo: RT, 2004. 